\title{
Penerapan Multiple Criteria Decision Making untuk Pemilihan Dosen Berprestasi
}

\author{
Implementation of Multiple Criteria Decision Making for Selection of Achieved \\ Lecturers
}

Tri Widayanti

Jurusan Sistem Informasi, STMIK Pontianak

Jl. Merdeka No. 372 Pontianak, Kalimantan Barat

E-mail: triwidayanti69@gmail.com

\begin{abstract}
Abstrak
Dengan adanya penyelenggaraan pemilihan dosen berprestasi di tingkat nasional, maka diharapkan setiap perguruan tinggi terdorong untuk memiliki sistem penghargaan yang terprogram bagi dosen yang memiliki prestasi tinggi dalam pelaksanaan tridarma perguruan tinggi. Dalam pemilihan dosen berprestasi tersebut sering muncul subyektifitas para pengambil keputusan.Tujuan dari penelitian ini adalah dengan penunjang keputusan, pengambilan keputusan akan lebih objektif dalam memilih dosen berprestasi. Penelitian Multiple Criteria Decision Making dilakukan dengan menggunakan 2 metode yaitu Analytical Hierarchy Process (AHP) dan Technique for Order by Similarity to Ideal Solution (TOPSIS). AHP digunakan untuk menentukan bobot kepentingan dari setiap kriteria dan sub kriteria penilaian dosen berprestasi, kemudian TOPSIS digunakan untuk memilih alternatif dosen berprestasi yang memerlukan pertimbangan. Hasil penelitian menunjukkan bahwa AHP dan TOPSIS dapat digunakan sebagai pendukung pembuat keputusan yang multi kriteria dan memerlukan banyak pertimbangan dalam pemilihan dosen berprestasi di perguruan tinggi. Metode AHP dan TOPSIS dapat membedakan dengan jelas berdasarkan nilai preferensi yang dihasilkan sehingga memberikan keputusan yang objektif.
\end{abstract}

Kata kunci : Dosen Berprestasi, Multiple Criteria Decision Making, AHP, TOPSIS

\begin{abstract}
Abstrak
With the implementation of high achievement lecturers selection at the national level, it is expected that each university is encouraged to have a rewards programmed system for lecturers who have high achievement as the implementation of college tridarma. Subjectivity of decision makers often appear in the selection of high achievement lecturers. The purpose of this study is by having a support decision, the decision making will be more objective in selecting the high achievement lecturers. Multiple Criteria Decision Making research is conducted using 2 methods of Analytical Hierarchy Process (AHP) and Technique for Order by Similarity to Ideal Solution (TOPSIS). AHP is used to determine the importance weight of each criterion and sub-criteria assessment of high achievement lecturers, then TOPSIS is used to select the alternative high achievement lecturers that require consideration. The results show that AHP and TOPSIS can be used as multi criteria decision makers and require many consideration in selection of the high achievement lecturers in universities. AHP and TOPSIS method can distinguish the value of resulting preference clearly, so it may provide an objective decision.
\end{abstract}

Key words : Achieved Lecturers, Multiple Criteria Decision Making, AHP, TOPSIS

\section{PENDAHULUAN}

Pendidikan Tinggi merupakan jenjang pendidikan setelah pendidikan menengah yang mencakup program diploma, program sarjana, program magister, program doktor, dan program profesi, serta program spesialis, yang diselenggarakan oleh perguruan tinggi berdasarkan 
kebudayaan bangsa Indonesia [1]. Sebagai upaya memetakan mutu dan potensi perguruan tinggi di Indonesia, Kementerian Riset, Teknologi dan Pendidikan Tinggi pada tahun 2017 melakukan pengelompokan atau klasterisasi perguruan tinggi dinilai dari empat komponen utama yaitu kualitas SDM, kualitas kelembagaan, kualitas kegiatan kemahasiswaan serta kualitas penelitian dan publikasi ilmiah. Selain itu Kementerian Riset, Teknologi, dan Pendidikan Tinggi mendorong peningkatan kualitas pendidikan vokasi melalui revitalisasi politeknik, maka klasterisasi perguruan tinggi Indonesia di kelompokan menjadi dua yaitu Politeknik dan Non-politeknik [2]. Dengan adanya klaterisasi tersebut masyarakat akan mendapatkan informasi yang valid terhadap perguruan tinggi.

Perguruan tinggi berkewajiban menyelenggarakan pendidikan, penelitian dan pengabdian kepada masyarakat. Salah satu unsur dalam penyelenggaraan pendidikan tinggi adalah dosen. Dosen merupakan tenaga akademik yang bertugas merencanakan dan melaksanakan proses pembelajaran, melakukan pembimbingan dan pelatihan, melakukan penelitian serta pengabdian kepada masyarakat. Berdasarkan Undang-undang Republik Indonesia No 14 Tahun 2005 tentang Guru dan Dosen, Pasal 51 Ayat (1) Butir b, bahwa dosen berhak mendapatkan promosi dan penghargaan sesuai dengan kinerja akademiknya [3].

Dengan adanya penyelenggaraan pemilihan dosen berprestasi di tingkat nasional, maka diharapkan setiap perguruan tinggi terdorong untuk memiliki sistem penghargaan yang terprogram bagi dosen yang memiliki prestasi tinggi dalam pelaksanaan tridarmanya. Selain itu dapat menjadi informasi yang berharga bagi perguruan tinggi untuk menentukan prioritas pengembangan menuju daya saing perguruan tinggi sesuai dengan yang diharapkan.

Merujuk pada klaterisasi dan undang-undang di atas telah merefleksi dan memotivasi Politeknik Negeri Pontianak (POLNEP) untuk meningkatan kualitas manajemen akademik dengan memberikan penghargaan yang diberikan kepada dosen yang memiliki prestasi di bidang tridarma perguruan tinggi. Pemberian penghargaan akan mendorong dosen untuk berprestasi secara produktif. Prestasi yang semakin produktif diharapkan dapat mendorong tercapainya tujuan pengembangan sistem pendidikan tinggi di POLNEP khususnya dan Pembangunan Nasional pada umumnya. Selain hal tersebut, untuk saat ini POLNEP termasuk peringkat 10 besar Perguruan Tinggi Politeknik di Indonesia tahun 2017 [2]. Sehingga hal tersebut memberikan motivasi POLNEP untuk selalu memperbaiki manajemen akademik agar lebih baik lagi yang salah satunya adalah pemilihan dosen berprestasi yang dilakukan setiap tahunnya. Dalam pemilihan dosen berprestasi tersebut sering muncul subyektifitas para pengambil keputusan, sehingga untuk menghindari hal tersebut peneliti menggunakan model Multiple Criteria Decision Making (MCDM) yaitu metode AHP dan TOPSIS untuk penunjang keputusan tersebut.

Model Multiple Criteria Decision Making (MCDM) sering digunakan untuk memecahkan masalah dalam dunia nyata dimana beberapa kriteria yang sering bertentangan harus dipertimbangkan [4]. Metode ini memungkinkan untuk membantu menyelesaikan masalah secara sistematis. Penelitian sebelumnya menunjukkan bahwa AHP dan TOPSIS dapat digunakan untuk mengevaluasi dan pemilihan negara sebagai penyedia jasa tenaga kerja dengan studi kasus di Asia Timur dan Tenggara [5]. Selain itu, digunakan juga untuk pemilihan mesin yang baik untuk peningkatan produksi dan menaikan pendapatan perusahaan [6]. AHP dan TOPSIS juga telah digunakan untuk memilih produsen terbaik yang akan membangun satelit sebagai alat untuk komunikasi [7]. Penelitian-penelitian tersebut telah menunjukkan bahwa AHP dan TOPSIS tepat digunakan untuk mendukung di dalam pengambilan keputusan dalam pemilihan alternatif yang terbaik sesuai dengan yang diinginkan, walaupun obyek penelitiannya berbeda-beda. Setiap obyek yang diteliti memiliki karakteristik yang berbeda-beda sehingga sangat menentukan jenis kriteria, sub kriteria, dan alternatif. Obyek penelitian yang saya lakukan berbeda dengan penelitian sebelumnya sehingga jenis kriteria, sub kriteria, dan alternatifnya juga berbeda.

Pengembangan dalam penunjang keputusan ini diharapkan dapat membantu dalam pemilihan dosen berprestasi sehingga akan lebih objektif dan dapat menjadi salah satu media untuk mendukung team seleksi dalam mengambil keputusan. 


\section{METODE PENELITIAN}

Penelitian ini dilakukan dengan menggunakan metode Multiple Criteria Decision Making (MCDM) yaitu suatu metode pengambilan keputusan untuk menetapkan alternatif terbaik dari sejumlah alternatif berdasarkan kriteria tertentu [8]. Metode MCDM memberikan kerangka kerja yang baik untuk proses pemilihan dosen berprestasi yang melibatkan faktor kualitatif dan kuantitatif. Dalam penelitian ini, metode MCDM yang digunakan adalah metode Analytical Hierarchy Process (AHP) dan Technique for Order by Similarity to Ideal Solution (TOPSIS).

AHP digunakan untuk menentukan bobot kepentingan dari setiap kriteria dan sub kriteria pemilihan dosen prestasi, kemudian TOPSIS digunakan untuk memilih alternatif dosen berprestasi didasarkan pada konsep dimana alternatif yang terbaik tidak hanya memiliki jarak terpendek dari solusi ideal positif, namun juga memiliki jarak terpanjang dari solusi ideal negatif [9].

\subsection{Metode AHP}

AHP merupakan metode pengambilan keputusan yang melibatkan sejumlah kriteria dan alternatif yang dipilih berdasarkan pertimbangan semua kriteria terkait [10]. Kriteria memiliki derajat kepentingan yang berbeda-beda, demikian pula halnya alternatif memiliki preferensi yang berbeda menurut masing-masing kriteria yang ada. Penilaian kriteria dan alternatif dilakukan dengan membuat perbandingan berpasangan (pairwise comparison) dengan menggunakan skala 1 sampai 9. Nilai dan definisi pendapat kualitatif dari skala 1 sampai 9 Saaty dapat diukur dan mempunyai arti yang dapat dilihat di tabel 1 [11].

Nilai-nilai perbandingan relatif dari seluruh alternatif kriteria disesuaikan dengan penilaian pembuat keputusan untuk menghasilkan bobot dan prioritas. Bobot dan prioritas dihitung dengan matriks atau diselesaikan melalui penyelesaian matematis. Apabila dijabarkan dalam tahapan, maka AHP dilakukan dengan beberapa tahapan berikut ini:

1. Membuat struktur hierarki.

2. Membangun pairwise comparison matrix.

Dengan asumsi $n$ atribut, perbandingan berpasangan atribut i dengan atribut $\mathrm{j}$ menghasilkan matriks $A_{n \times n}$ dimana $a_{i j}$ menunjukkan pentingnya perbandingan atribut $i$ dengan atribut $j$. Dalam matriks, $\mathrm{a}_{\mathrm{ij}}=1$ ketika $\mathrm{i}=\mathrm{j}$ dan $\mathrm{a}_{\mathrm{ji}}=1 / \mathrm{a}_{\mathrm{ij}}$.

$$
\begin{aligned}
& \text { Atribut }
\end{aligned}
$$

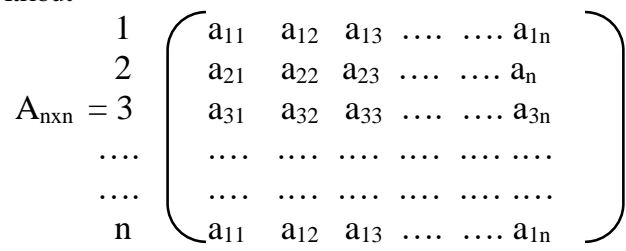

3. Menyusun matriks keputusan ternormalisasi :

$$
\begin{aligned}
& \mathrm{C}_{\mathrm{ij}}=\mathrm{a}_{\mathrm{ij}} / \sum_{J=1}^{n} \text { aij } \\
& \mathrm{I}=1,2,3, \ldots \ldots \ldots, \mathrm{n}, \mathrm{j}=1,2,3, \ldots \ldots ., \mathrm{n}
\end{aligned}
$$

4.Menyusun Matriks Keputusan Normalisasi Terbobot.

$$
\begin{aligned}
& \mathrm{w}_{\mathrm{i}}=\sum_{J=1}^{n} \text { aij } / \mathrm{n}, \mathrm{I}=1,2,3, \ldots \ldots \mathrm{n} \\
& \mathrm{w}=\left(\begin{array}{c}
\mathrm{w}_{1} \\
\mathrm{w}_{2} \\
\cdot \\
\mathrm{w}_{\mathrm{n}}
\end{array}\right)
\end{aligned}
$$

5. Menghitung Eigenvector dan matriks baris 
$\mathrm{E}=\mathrm{N}^{\text {th }}$ rootvalue $/ \sum \mathrm{N}^{\text {th }}$ rootvalue

Rowmatrix $=\sum_{J=1}^{n} a i j * \mathrm{e}_{\mathrm{j} 1}$

6.Menghitung Eigenvalue maksimal, $\lambda_{\max }$

$$
\lambda_{\max }=\text { Rowmatrix / E }
$$

7.Menghitung Consistency Index and Consistency Ratio

$$
\mathrm{CI}=\left(\lambda_{\max }-\mathrm{n}\right) /(\mathrm{n}-1)
$$

$$
\mathrm{CR}=\mathrm{CI} / \mathrm{RI}
$$

Hasil perhitungan akan menghasilkan Logical Consistency. Pemilihan kriteria harus konsisten. Konsistensi disini memiliki dua makna. Pertama, objek-objek yang serupa bisa dikelompokkan sesuai dengan keseragaman dan relevansi. Kedua, menyangkut tingkat hubungan antar objek yang didasarkan pada kriteria tertentu. Konsistensi dapat dihitung dengan menggunakan rumus Consistency Index $(\mathrm{CI})=(\lambda$ maks $) / \mathrm{n}$. Dimana $\mathrm{n}=$ banyaknya elemen. Setelah itu perlu menghitung Consistency Ratio (CR) dengan rumus: CR = CI/RI. Jika CR kurang dari 10\% maka penilaian pembuat keputusan dianggap konsisten dan bila lebih dari 10\% berarti tidak konsisten dan harus diulang penilaiannya. RI adalah Random Consistency dengan ukuran matriks 1 sampai 9 dengan nilai sesuai ukuran matriks yang dapat dilihat pada tabel 2 .

Tabel 1 : Skala Penilaian Perbandingan Pasangan Saaty

\begin{tabular}{|c|l|}
\hline IntensitasKepentingan & \multicolumn{1}{c|}{ Keterangan } \\
\hline 1 & Kedua elemen sama penting \\
\hline 3 & Elemen yang satu sedikit lebih penting dari pada elemen lainnya \\
\hline 5 & Elemen yang satu lebih penting dari pada elemen lainnya \\
\hline 7 & Satu elemen jelas lebih mutlak penting dari pada elemen lainnya \\
\hline 9 & Satu elemen mutlak penting dari pada elemen lainnya \\
\hline 2468 & Nilai - nilai antara dua nilai pertimbangan yang berdekatan \\
\hline
\end{tabular}

Tabel 2. Nilai Rata-Rata Konsistensi

\begin{tabular}{|c|c|}
\hline Ukuran Matriks & Random Consistency \\
\hline 1 dan 2 & 0,00 \\
\hline 3 & 0,58 \\
\hline 4 & 0,90 \\
\hline 5 & 1,12 \\
\hline 6 & 1,24 \\
\hline 7 & 1,32 \\
\hline 8 & 1,41 \\
\hline 9 & 1,45 \\
\hline 10 & 1,49 \\
\hline
\end{tabular}

\subsection{Metode TOPSIS}

TOPSIS merupakan suatu metode pendukung keputusan yang menggunakan prinsip bahwa alternatif yang terpilih harus mempunyai jarak terdekat dari solusi ideal positif dan terjauh dari solusi ideal negatif dari sudut pandang geometris dengan menggunakan jarak Euclidean untuk menentukan kedekatan relatif dari suatu alternatif dengan solusi optimal.

Solusi ideal positif didefinisikan sebagai jumlah dari seluruh nilai terbaik yang dapat dicapai untuk setiap atribut, sedangkan solusi negatif ideal terdiri dari seluruh nilai terburuk yang 
dicapai untuk setiap atribut [8]. TOPSIS mempertimbangkan keduanya, jarak terhadap solusi ideal positif dan jarak terhadap solusi ideal negatif dengan mengambil kedekatan relatif terhadap solusi ideal positif. Berdasarkan perbandingan terhadap jarak relatifnya, susunan prioritas alternatif bisa dicapai.

Metode TOPSIS ini merupakan salah satu metode yang digunakan sebagai upaya untuk menyelesaikan permasalahan MCDA.Secara umum, metode TOPSIS memiliki langkah-langkah sebagai berikut : $[7,8]$

a. Menggambarkan alternatif (m) dan kriteria (n) kedalam sebuah matriks, dimana $X_{\mathrm{ij}}$ adalah pengukuran pilihan dari alternatif ke-I dan kriteria ke-j.

$$
\mathrm{D}=\left[\begin{array}{llll}
x_{11} & x_{12} \ldots & x_{14} \\
x_{21} & x_{22} \ldots & x_{24} \\
x_{i 1} & x_{32} \ldots & x_{i j}
\end{array}\right]
$$

b. Membangun normalized decision matrix Elemen $\mathrm{r}_{\mathrm{ij}}$ hasil dari normalisasi decision matrix $\mathrm{R}$ dengan metode Euclidean length of a vector adalah :

$$
\mathrm{r}_{\mathrm{ij}}=\frac{X_{i j}}{\sqrt{\sum_{i=1}^{m} X_{i j}^{2}}}
$$

Dimana : $\mathrm{r}_{\mathrm{ij}}=$ hasil dari normalisasi matriks keputusan $\mathrm{R}$

$\mathrm{i}=1,2,3, \ldots, \mathrm{m}$;

$\mathrm{j}=1,2,3, \ldots, \mathrm{n}$;

c. Membangun weighted normalized decision matrix. Setelah dinormalisasi, setiap kolom pada matriks $\mathrm{R}$ dikalikan dengan bobot $\left(\mathrm{W}_{\mathrm{j}}\right)$, maka normalisasi bobot matriks $\mathrm{V}$ adalah:

$$
\mathrm{V}=\left[\begin{array}{ccc}
w_{1} r_{11} & w_{1} r_{12} \ldots & w_{n} r_{1 n} \\
w_{2} r_{21} & \ldots & \ldots \\
w_{i} r_{m 1} & w_{j} r_{m 2} \ldots & w_{j} r_{m n}
\end{array}\right]
$$

d. Menentukan solusi ideal positif dan solusi ideal negatif.

$$
\begin{aligned}
\mathrm{A}^{+} & =\left\{\left(\max \mathrm{V}_{\mathrm{ij}} \mid \mathrm{j} \in \mathrm{J}\right),\left(\min \mathrm{V}_{\mathrm{ij}} \mid \mathrm{j} \in \mathrm{J}^{\prime}\right), \mathrm{i}=1,2,3, \ldots, \mathrm{m}\right\} \\
& =\left\{\mathrm{V}_{1^{+}}, \mathrm{V}_{\mathrm{V}^{+}}, \ldots, \mathrm{V}_{\mathrm{n}}{ }^{+}\right\} \\
\mathrm{A}^{-} & =\left\{\left(\min \mathrm{V}_{\mathrm{ij}} \mid \mathrm{j} \in \mathrm{J}\right),\left(\max \mathrm{V}_{\mathrm{ij}} \mid \mathrm{j} \in \mathrm{J}^{\prime}\right), \mathrm{i}=1,2,3, \ldots, \mathrm{m}\right\} \\
& =\left\{\mathrm{V}_{1}^{-}, \mathrm{V}_{2}^{-}, \ldots, \mathrm{V}_{\mathrm{n}}^{-}\right\} \\
\mathrm{J} & =\{\mathrm{j}=1,2,3, \ldots . \mathrm{n} \text { dan } \mathrm{j} \text { merupakan benefit criteria }\} \\
\mathrm{J}^{\prime} & =\{\mathrm{j}=1,2,3, \ldots . \mathrm{n} \text { dan } \mathrm{j} \text { merupakan cost criteria })\}
\end{aligned}
$$

e. Menghitung separation measure. Separation measure merupakan pengukuran jarak dari suatu alternatif ke solusi ideal positif dan solusi ideal negatif.

$$
\begin{aligned}
& \mathrm{S}_{\mathrm{i}}^{+}=\sqrt{\sum_{i=1}^{n}\left(V_{i j}-V_{j}^{+}\right)^{2}} \\
& \mathrm{~S}_{\mathrm{i}}^{-}=\sqrt{\sum_{i=1}^{n}\left(V_{i j}-V_{j}^{-}\right)^{2}} \\
& \text { Dengan } \mathrm{i}=1,2,3 \ldots \ldots . \mathrm{m}
\end{aligned}
$$

f. Menghitung nilai preferensi untuk setiap alternatif untuk menentukan ranking tiap-tiap alternatif yang ada.

$$
\mathrm{C}_{\mathrm{i}}^{+}=\frac{S_{i}^{-}}{S_{i}^{+}+S_{i}^{-}}
$$


Dimana $0<\mathrm{C}_{\mathrm{i}}^{+}<1$ dan $\mathrm{I}=1,2,3, \ldots \ldots, \mathrm{m}$

\subsection{Kriteria Penilaian Dosen Berpretasi}

Berdasarkan hasil wawancara dengan tim penilai dosen terbaik berdasarkan prestasi akademik pada Politeknik Negeri Pontianak didapatkan 5 kriteria penting yang berpengaruh dalam penilaian dosen tersebut. Adapun kriteria tersebut adalah kinerja bidang pendidikan, kinerja bidang penelitian, kinerja bidang pengabdian masyarakat, kinerja bidang penunjang lainya dan kualifikasi pendidikan atau jabatan akademik.

Agar didalam penilaian dosen lebih proposional maka perlu adanya subkriteria untuk tiap-tiap kriterianya. Kriteria dan subkriteria yang dikembangkan lebih lanjut dari hasil wawancara dapat dilihat pada gambar 1 berikut ini :

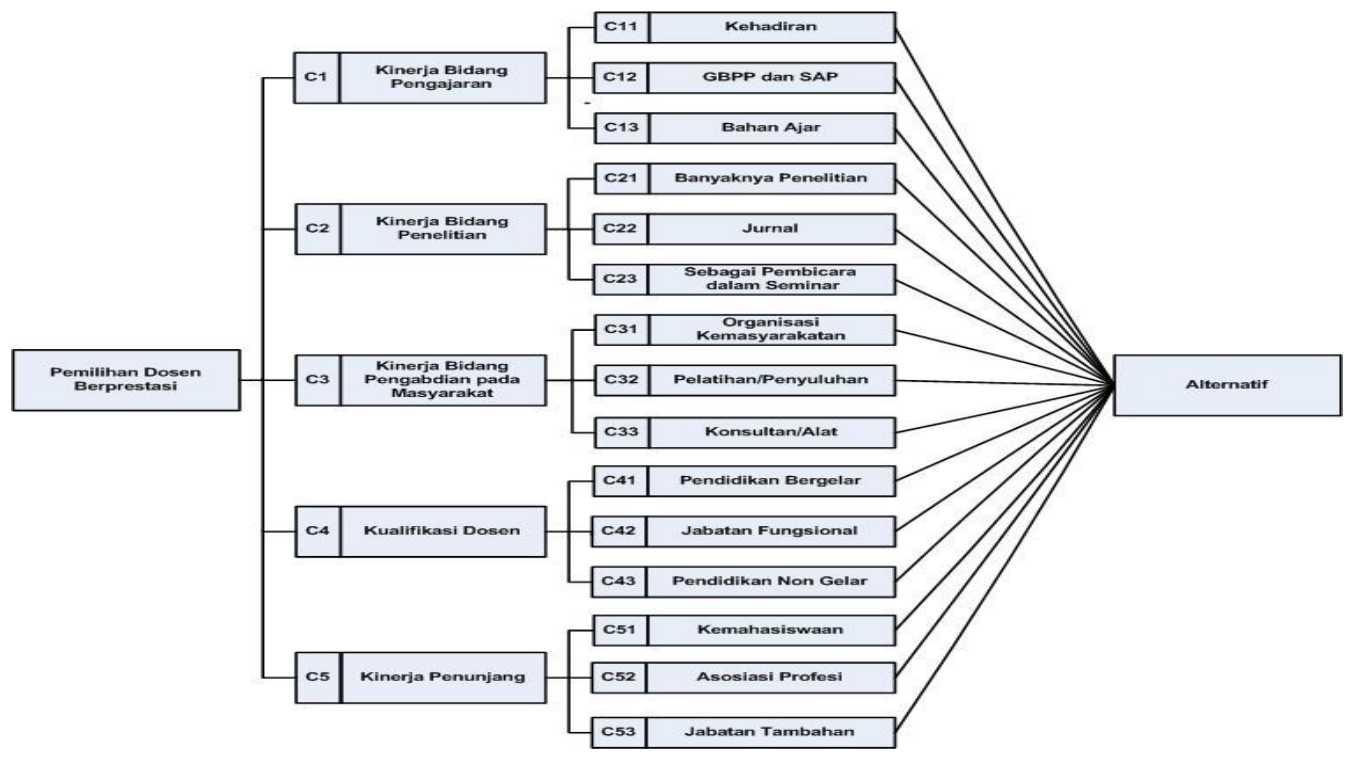

Gambar 1.Hirarki Pemilihan Dosen Berprestasi

Kinerja Bidang Pendidikan berkaitan dengan karakter dari pengajaran yang dilakukan oleh dosen. Sebelum mengajar dosen tidak hanya melakukan absensi kehadiran saja tetapi dosen juga harus memiliki GBPP dan SAP demi kelancaran dan keberhasilan dalam proses belajar mengajar. GBPP (Garis Besar Program Pengajaran) merupakan petunjuk secara lengkap setiap pertemuan kuliah secara rinci dengan tujuan perkuliahan, ruang lingkup, media yang digunakan serta materi yang diajarkan. Sedangkan SAP (Satuan Acara Pengajaran) merupakan pokok pengajaran yang meliputi satu atau beberapa pokok bahasan untuk diajarkan selama satu kali atau beberapa kali pertemuan. Dengan adanya GBPP dan SAP dosen dapat terarah dan terstruktur dalam menyampaikan materi perkuliahan. Selain itu dosen juga harus memiliki Bahan Ajar yang dibuat sendiri sebagai penunjang proses pembelajaran yang memiliki angka kredit sesuai bobot produk yang dihasilkan serta penunjang proses akreditasi program studi. Dosen yang baik akan memiliki kelengkapan tersebut.

Kinerja Bidang Penelitian berkaitan dengan kemampuan dosen melakukan penelitian, serta melakukan publikasi hasil penelitian dalam bentuk jurnal ilmiah dan sebagai narasumber dalam seminar ilmiah baik lokal, nasional, maupun internasional dalam setiap tahunnya. Seringkali dosen mengabaikan penelitian yang merupakan salah satu dari tridarma perguruan tinggi. Hal tersebut sangat berpengaruh terhadap kualitas dosen di perguruan tinggi yang bersangkutan. Semakin banyak dosen melakukan penelitian, publikasi ilmiah, dan menjadi narasumber dalam seminar ilmiah semakin baik kinerja dosen di bidang tersebut. 
Kinerja Bidang Pengabdian Masyarakat merupakan kriteria di bidang Pengabdian Masyarakat dengan melakukan penyuluhan/pelatihan, memberikan bantuan peralatan, dan menjadi konsultan bagi masyarakat sesuai dengan disiplin ilmu yang dimiliki dosen yang bersangkutan. Selain itu juga keterlibatan dosen dalam organisasi kemasyarakatan termasuk dalam kriteria bidang pengabdian kepada masyarakat. Jika dosen tidak pernah melakukan pengabdian berarti salah satu unsur tridarma perguruan tinggi tidak terpenuhi, yang berarti tridarma perguruan tinggi yang dilaksanakan menjadi tidak seimbang, pada hal tridarma perguruan tinggi tersebut merupakan kewajiban yang harus dilaksanakan dosen.

Kualifikasi dosen merupakan kriteria penilaian dosen yang berkaitan dengan pendidikan bergelar, non gelar, dan jabatan fungsional. Pendidikan bergelar yang dimiliki dosen merupakan sumber daya manusia utama sebuah perguruan tinggi. Semakin tinggi pendidikan bergelar seorang dosen semakin tinggi tingkat kepercayaan masyarakat terhadap perguruan tinggi tersebut. Pendidikan non gelar juga tidak kalah pentingnya dengan pendidikan gelar, lebih-lebih pendidikan non gelar yang dimiliki dosen sesuai dengan kompetensi mata kuliah yang diampu dosen tersebut. Semakin banyak pendidikan non gelar yang dimiliki oleh dosen maka kompetensi semakin meningkat yang akan berimbas pada peningkatan kualitas lulusan perguruan tinggi tersebut. Sedangkan untuk jabatan fungsional menunjukkan tingkat kinerja yang telah dilakukan dosen selama mengabdi di perguruan tinggi tersebut. Jabatan fungsional diperoleh berdasarkan pelaksanaan tridarma perguruan tinggi selama dosen mengabdi di perguruan tinggi tersebut. Semakin tinggi jabatan fungsional dosen berarti semakin tinggi kinerja di bidang tridarma perguruan tinggi.

Kinerja penunjang merupakan kriteria penilaian dosen yang berhubungan dengan kemahasiswaan, asosiasi profesi dan jabatan tambahan. Keterlibatan dosen di bidang kemahasiswaan meliputi : pembina Unit Kegiatan Mahasiswa (UKM), pembina Himpunan Mahasiswa Jurusan (HMJ), dan Pembimbing Program Kreativitas Mahasiswa (PKM). Asosiasi profesi merupakan organisasi yang memberikan pengakuan profesi sesuai dengan disiplin ilmu yang dimiliki seseorang. Sedangkan jabatan tambahan adalah jabatan struktural yang diamanahkan kepada dosen. Jabatan tambahan ini merupakan jabatan yang tidak terkait dengan tridarma perguruan tinggi. Keterlibatan dosen baik dalam kegiatan kemahasiswaan, asosiasi profesi, dan jabatan tambahan secara tidak langsung memberikan kontribusi dalam meningkatkan atmosfir akademik sebuah perguruan tinggi.

\section{HASIL DAN PEMBAHASAN}

\subsection{Bobot Kepentingan Kriteria Utama}

Pair-wise comparation dalam proses AHP merupakan perbandingan dari kriteria kinerja bidang pengajaran, kinerja bidang penelitian, kinerja bidang pengabdian masyarakat, kualifikasi dosen dan kinerja pendukung. Kriteria-kriteria tersebut diisi nilai bobotnya berdasarkan tingkat kepentingan dari masing-masing kriteria. Nilai perbandingan kriteria didapat dari kuesioner yang diberikan kepada panitia penilai dosen berprestasi di Politeknik Negeri Pontianak. Hasil perbandingan, normalisasi matriks kriteria, dan konsistensi dapat dilihat pada tabel 4 .

Tabel 4.Matrik Perbandingan, Normalisasi, Konsistensi Kriteria Utama

\begin{tabular}{|l|c|c|c|c|c|c|c|c|c|c|c|}
\hline & \multicolumn{2}{|c|}{ KB. } & \multicolumn{2}{c|}{ KB. } & \multicolumn{2}{c|}{ Kualifikasi D } & \multicolumn{2}{c|}{ Kinerja P } & EV \\
\hline KB. Pengajaran & 1.00 & 0.20 & 2.00 & 0.36 & 4.00 & 0.39 & 0.33 & 0.13 & 6.00 & 0.32 & 0.28 \\
\hline KB. Penelitian & 0.50 & 0.10 & 1.00 & 0.18 & 3.00 & 0.29 & 0.50 & 0.20 & 4.00 & 0.21 & 0.20 \\
\hline KB.Pengabdian & 0.25 & 0.05 & 0.33 & 0.06 & 1.00 & 0.10 & 0.50 & 0.20 & 3.00 & 0.16 & 0.11 \\
\hline Kualifikasi D & 3.00 & 0.61 & 2.00 & 0.36 & 2.00 & 0.19 & 1.00 & 0.39 & 5.00 & 0.26 & 0.36 \\
\hline Kinerja P. & 0.17 & 0.03 & 0.25 & 0.04 & 0.33 & 0.03 & 0.20 & 0.08 & 1.00 & 0.05 & 0.05 \\
\hline JUMLAH & 4.92 & 0.97 & 5.58 & 0.96 & 10.33 & 0.97 & 2.53 & 0.92 & 6.00 & 1.00 & 1.00 \\
\hline \multicolumn{3}{|c|}{ Consistency Index (CI) } \\
\hline
\end{tabular}


Consistency Rasio (CR)

$\mathrm{CR}=0.0832 /$ Konsisten

Perbandingan berpasangan pada tabel 4 diperoleh dari penitia penilai dosen berprestasi dengan menggunakan persamaan 1 untuk mendapatkan nilai normalisasi masing-masing kriteria. Selanjutnya dari persamaan 2 didapatkan hasil akhir berupa Eigen Value atau bobot setiap elemen. Eigen Value dari setiap kriteria utama adalah Kinerja Bidang Pengajaran 0.28, Kinerja Bidang Penelitian 0.20, Kinerja Bidang Pengabdian 0.11, Kualifikasi Dosen 0.36, dan Kinerja Penunjang 0.05. Berdasarkan hasil EV dapat disimpulkan bahwa kriteria paling penting dalam penilaian dosen berprestasi adalah kriteria Kualifikasi Dosen, diikuti dengan Kinerja Bidang Pengajaran, Kinerja Bidang Penelitian, Kinerja Bidang Pengabdian Masyarakat dan terakhir Kinerja Penunjang. Seperti terlihat pada gambar 2.

Untuk menilai konsistensi kriteria, perhitungan CR dilakukan sesuai dengan persamaan 8 dengan RI menggunakan matriks $5 \times 5$ yang bernilai 1.12. Hasil CR menunjukkan nilai 0.0832 yang berarti lebih rendah dari 0.1 sehingga dianggap konsisten. [10,11]

\subsection{Bobot Kepentingan Sub Kriteria}

Tahap selanjutnya adalah proses pair-wise comparation untuk sub kriteria yang kemudian dilanjutkan dengan normalisasi matriks sub kriteria dan menghasilkan Eigen Value seperti terlihat pada tabel 5. Hasil Eigen Value untuk sub kriteria dapat disimpulkan bahwa untuk sub kriteria Kinerja Bidang Pengajaran yang paling penting adalah sub kriteria Kehadiran, GBPP dan SAP dan diikuti dengan Bahan Ajar. Sub kriteria Kinerja Bidang Penelitian yang paling penting adalah Banyaknya Penelitian kemudian Jurnal dan yang terakhir pembicara dalam seminar.

Kinerja Bidang Pengabdian Masyarakat memiliki sub kriteria yang penting adalah Pelatihan/Penyuluhan, Konsultasi/Alat dan diikuti Organisasi Kemasyarakatan. Sub kriteria Kualifikasi Dosen yang terpenting adalah Pendidikan Bergelar diikuti sub kriteria Jabatan Fungsional dan Pendidikan Non Gelar. Sedangkan sub kriteria Kinerja Penunjang yang tertinggi adalah Asosiasi Profesi kemudian Jabatan Tambahan dan yang terakhir Kemahasiswaan.

Semua perbandingan berpasangan diuji konsistensi dengan RI bernilai 0.58 (bermatriks $3 \times 3$ ) dan semuanya memenuhi syarat dengan nilai dibawah 0.1 atau $10 \%$, dengan demikian dapat disimpulkan bahwa perbandingan untuk sub kriteria telah memenuhi syarat.

Tabel 5. Matriks Perbandingan Berpasangan Sub Kriteria

KB. PENGAJARAN

\begin{tabular}{|l|l|l|l|l|l|l|l|}
\hline & \multicolumn{2}{|c|}{$\mathrm{C} 11$} & \multicolumn{2}{c|}{$\mathrm{C} 12$} & \multicolumn{2}{c|}{$\mathrm{C} 13$} & $\mathrm{EV}$ \\
\hline $\mathrm{C} 11$ & 1.00 & 0.55 & 2.00 & 0.57 & 3.00 & 0.50 & 0.54 \\
\hline $\mathrm{C} 12$ & 0.50 & 0.27 & 1.00 & 0.29 & 2.00 & 0.33 & 0.30 \\
\hline $\mathrm{C} 13$ & 0.33 & 0.18 & 0.50 & 0.14 & 1.00 & 0.17 & 0.16 \\
\hline JML & 1.83 & 1.00 & 3.50 & 1.00 & 6.00 & 1.00 & 1.00 \\
\hline \multicolumn{3}{|c|}{ Consistency Index } & \multicolumn{3}{c|}{$\mathrm{CI}=0.0046 \mathrm{RI}=0.58$} \\
\hline \multicolumn{3}{|c|}{ Consistency Ratio } & \multicolumn{3}{c}{$\mathrm{CR}=0.0079 /$ Konsisten } \\
\hline
\end{tabular}

\section{KB. PENGABDIAN}

\begin{tabular}{|l|c|c|c|c|c|c|c|}
\hline & \multicolumn{2}{|c|}{ C21 } & \multicolumn{2}{c|}{ C22 } & \multicolumn{2}{c|}{ C23 } & EV \\
\hline C31 & 1.00 & 0.14 & 0.25 & 0.16 & 0.50 & 0.11 & 0.14 \\
\hline C32 & 4.00 & 0.57 & 1.00 & 0.63 & 3.00 & 0.67 & 0.62 \\
\hline C33 & 2.00 & 0.29 & 0.33 & 0.21 & 1.00 & 0.22 & 0.24 \\
\hline JML & 7.00 & 1.00 & 1.58 & 1.00 & 4.50 & 1.00 & 1.00 \\
\hline \multicolumn{3}{|c|}{ Consistency Index } & \multicolumn{3}{c|}{ CI $=0.0092$ RI $=0.58$} \\
\hline \multicolumn{3}{|c|}{ Consistency Ratio } & \multicolumn{3}{c|}{ CR $=0.0158 /$ Konsisten } \\
\hline
\end{tabular}

KB. PENELITIAN

\begin{tabular}{|l|l|l|l|l|l|l|l|}
\hline & \multicolumn{2}{|c|}{ C21 } & \multicolumn{2}{c|}{ C22 } & \multicolumn{2}{c|}{ C23 } & EV \\
\hline $\mathrm{C} 21$ & 1.00 & 0.63 & 4.00 & 0.73 & 3.00 & 0.50 & 0.62 \\
\hline $\mathrm{C} 22$ & 0.25 & 0.16 & 1.00 & 0.18 & 2.00 & 0.33 & 0.22 \\
\hline $\mathrm{C} 23$ & 0.33 & 0.21 & 0.50 & 0.09 & 1.00 & 0.17 & 0.16 \\
\hline JML & 1.58 & 1.00 & 5.50 & 1.00 & 6.00 & 1.00 & 1.00 \\
\hline \multicolumn{3}{|c|}{ Consistency Index } & \multicolumn{3}{c|}{$\mathrm{CI}=0.0546 \mathrm{RI}=0.58$} \\
\hline \multicolumn{3}{|c|}{ Consistency Ratio } & \multicolumn{3}{c|}{$\mathrm{CR}=0.0942 /$ Konsisten } \\
\hline
\end{tabular}

KUALIFIKASI DOSEN

\begin{tabular}{|l|l|l|l|l|l|l|l|}
\hline & \multicolumn{2}{|c|}{ C31 } & \multicolumn{2}{c|}{ C32 } & \multicolumn{2}{c|}{ C33 } & EV \\
\hline C41 & 1.00 & 0.55 & 2.00 & 0.60 & 3.00 & 0.43 & 0.52 \\
\hline C42 & 0.50 & 0.27 & 1.00 & 0.30 & 3.00 & 0.43 & 0.33 \\
\hline C43 & 0.33 & 0.18 & 0.33 & 0.10 & 1.00 & 0.14 & 0.14 \\
\hline JML & 1.83 & 1.00 & 3.33 & 1.00 & 7.00 & 1.00 & 1.00 \\
\hline \multicolumn{3}{|c|}{ Consistency Index } & \multicolumn{3}{c|}{ CI $=0.0269$ RI $=0.58$} \\
\hline \multicolumn{3}{|c|}{ Consistency Ratio } & CR $=0.0464 /$ Konsisten \\
\hline
\end{tabular}


KINERJA PENUNJANG

\begin{tabular}{|l|c|c|c|c|c|c|c|}
\hline & \multicolumn{2}{|c|}{ C31 } & \multicolumn{2}{c|}{ C32 } & \multicolumn{2}{c|}{ C33 } & EV \\
\hline C51 & 1.00 & 0.13 & 0.25 & 0.14 & 0.33 & 0.10 & 0.12 \\
\hline C52 & 4.00 & 0.50 & 1.00 & 0.57 & 2.00 & 0.60 & 0.56 \\
\hline C53 & 3.00 & 0.38 & 0.50 & 0.29 & 1.00 & 0.30 & 0.32 \\
\hline JUMLAH & 8.00 & 1.00 & 1.75 & 1.00 & 3.33 & 1.00 & 1.00 \\
\hline \multicolumn{4}{|c|}{ Consistency Index (CI) } & \multicolumn{4}{c|}{ CI $=0.0092$ RI $=0.58$} \\
\hline \multicolumn{4}{|c|}{ Consistency Ratio (CR) } & \multicolumn{4}{c|}{ CR $0158 /$ Konsisten } \\
\hline
\end{tabular}

Tabel 6. Hasil Penilaian Dosen Untuk Dosen Berprestasi

\begin{tabular}{|l|c|c|c|c|c|c|c|c|c|c|c|c|c|c|c|}
\hline Alternatif & C11 & C12 & C13 & C21 & C22 & C23 & C31 & C32 & C33 & C41 & C42 & C43 & C51 & C52 & C53 \\
\hline Iwan Darmawan & 3 & 3 & 3 & 3 & 4 & 4 & 3 & 5 & 3 & 5 & 4 & 3 & 3 & 3 & 2 \\
\hline Rina Asparina & 5 & 3 & 3 & 4 & 4 & 4 & 1 & 5 & 1 & 3 & 3 & 3 & 1 & 3 & 3 \\
\hline Masrudi & 5 & 3 & 3 & 2 & 5 & 5 & 2 & 3 & 3 & 3 & 3 & 2 & 1 & 3 & 2 \\
\hline Agus Fatarudi & 5 & 3 & 3 & 5 & 3 & 3 & 3 & 5 & 5 & 3 & 4 & 3 & 3 & 3 & 1 \\
\hline Dewi Utami Putri & 5 & 3 & 3 & 4 & 4 & 3 & 1 & 3 & 5 & 5 & 4 & 2 & 1 & 1 & 2 \\
\hline Denny Sarmadi & 3 & 3 & 3 & 2 & 1 & 4 & 1 & 1 & 5 & 5 & 4 & 2 & 1 & 3 & 2 \\
\hline Asnandar & 5 & 3 & 3 & 4 & 5 & 5 & 1 & 5 & 1 & 3 & 3 & 1 & 1 & 1 & 1 \\
\hline Ardilia Az Zahra & 5 & 3 & 3 & 4 & 4 & 4 & 2 & 1 & 1 & 1 & 2 & 3 & 3 & 1 & 1 \\
\hline Iyan Sampuraga & 3 & 3 & 3 & 5 & 4 & 4 & 2 & 3 & 3 & 3 & 3 & 2 & 3 & 3 & 1 \\
\hline Sri Ayu Ningsih & 5 & 3 & 3 & 3 & 4 & 4 & 1 & 5 & 1 & 3 & 4 & 1 & 3 & 1 & 1 \\
\hline & 14.21 & 8.94 & 9.49 & 11.83 & 12.49 & 12.81 & 5.92 & 12.41 & 10.30 & 11.40 & 10.95 & 7.35 & 7.07 & 7.62 & 5.48 \\
\hline
\end{tabular}

Tabel 7. Normalized Decision Matrix

\begin{tabular}{|l|l|l|l|l|l|l|l|l|l|l|l|l|l|l|l|}
\hline Alternatif & C11 & C12 & C13 & C21 & C22 & C23 & C31 & C32 & C33 & C41 & C42 & C43 & C51 & C52 & C53 \\
\hline Iwan Darmawan & 0.21 & 0.32 & 0.32 & 0.25 & 0.32 & 0.31 & 0.51 & 0.40 & 0.29 & 0.44 & 0.37 & 0.41 & 0.42 & 0.39 & 0.37 \\
\hline Rina Asparina & 0.35 & 0.32 & 0.32 & 0.34 & 0.32 & 0.31 & 0.17 & 0.40 & 0.10 & 0.26 & 0.27 & 0.41 & 0.14 & 0.39 & 0.55 \\
\hline Masrudi & 0.35 & 0.32 & 0.32 & 0.17 & 0.40 & 0.39 & 0.34 & 0.24 & 0.29 & 0.26 & 0.27 & 0.27 & 0.14 & 0.39 & 0.37 \\
\hline Agus Fatarudi & 0.35 & 0.32 & 0.32 & 0.42 & 0.24 & 0.23 & 0.51 & 0.40 & 0.49 & 0.26 & 0.37 & 0.41 & 0.42 & 0.39 & 0.18 \\
\hline Dewi Utami Putri & 0.35 & 0.32 & 0.32 & 0.34 & 0.32 & 0.23 & 0.17 & 0.24 & 0.49 & 0.44 & 0.37 & 0.27 & 0.14 & 0.13 & 0.37 \\
\hline Denny Sarmadi & 0.21 & 0.32 & 0.32 & 0.17 & 0.08 & 0.31 & 0.17 & 0.08 & 0.49 & 0.44 & 0.37 & 0.27 & 0.14 & 0.39 & 0.37 \\
\hline Asnandar & 0.35 & 0.32 & 0.32 & 0.34 & 0.40 & 0.39 & 0.17 & 0.40 & 0.10 & 0.26 & 0.27 & 0.14 & 0.14 & 0.13 & 0.18 \\
\hline Ardilia Az Zahra & 0.35 & 0.32 & 0.32 & 0.34 & 0.32 & 0.31 & 0.34 & 0.08 & 0.10 & 0.09 & 0.18 & 0.41 & 0.42 & 0.13 & 0.18 \\
\hline Iyan Sampuraga & 0.21 & 0.32 & 0.32 & 0.42 & 0.32 & 0.31 & 0.34 & 0.24 & 0.29 & 0.26 & 0.27 & 0.27 & 0.42 & 0.39 & 0.18 \\
\hline Sri Ayu Ningsih & 0.35 & 0.32 & 0.32 & 0.25 & 0.32 & 0.31 & 0.17 & 0.40 & 0.10 & 0.26 & 0.37 & 0.14 & 0.42 & 0.13 & 0.18 \\
\hline
\end{tabular}

Tabel 8. Weighted Normalized Decision Matrix

\begin{tabular}{|l|c|c|c|c|c|c|c|c|c|c|c|c|c|c|c|}
\hline Alternatif & C11 & C12 & C13 & C21 & C22 & C23 & C31 & C32 & C33 & C41 & C42 & C43 & C51 & C52 & C53 \\
\hline Iwan Darmawan & 0.02 & 0.17 & 0.11 & 0.05 & 0.23 & 0.03 & 0.11 & 0.25 & 0.05 & 0.06 & 0.12 & 0.13 & 0.06 & 0.20 & 0.13 \\
\hline Rina Asparina & 0.04 & 0.17 & 0.11 & 0.07 & 0.23 & 0.03 & 0.04 & 0.25 & 0.02 & 0.04 & 0.09 & 0.13 & 0.02 & 0.20 & 0.20 \\
\hline Masrudi & 0.04 & 0.17 & 0.11 & 0.03 & 0.28 & 0.04 & 0.07 & 0.15 & 0.05 & 0.04 & 0.09 & 0.09 & 0.02 & 0.20 & 0.13 \\
\hline Agus Fatarudi & 0.04 & 0.17 & 0.11 & 0.08 & 0.17 & 0.02 & 0.11 & 0.25 & 0.08 & 0.04 & 0.12 & 0.13 & 0.06 & 0.20 & 0.07 \\
\hline Dewi Utami Putri & 0.04 & 0.17 & 0.11 & 0.07 & 0.23 & 0.02 & 0.04 & 0.15 & 0.08 & 0.06 & 0.12 & 0.09 & 0.02 & 0.07 & 0.13 \\
\hline Denny Sarmadi & 0.02 & 0.17 & 0.11 & 0.03 & 0.06 & 0.03 & 0.04 & 0.05 & 0.08 & 0.06 & 0.12 & 0.09 & 0.02 & 0.20 & 0.13 \\
\hline Asnandar & 0.04 & 0.17 & 0.11 & 0.07 & 0.28 & 0.04 & 0.04 & 0.25 & 0.02 & 0.04 & 0.09 & 0.04 & 0.02 & 0.07 & 0.07 \\
\hline Ardilia Az Zahra & 0.04 & 0.17 & 0.11 & 0.07 & 0.23 & 0.03 & 0.07 & 0.05 & 0.02 & 0.01 & 0.06 & 0.13 & 0.06 & 0.07 & 0.07 \\
\hline
\end{tabular}




\begin{tabular}{|l|c|c|c|c|c|c|c|c|c|c|c|c|c|c|c|} 
Iyan Sampuraga & 0.02 & 0.17 & 0.11 & 0.08 & 0.23 & 0.03 & 0.07 & 0.15 & 0.05 & 0.04 & 0.09 & 0.09 & 0.06 & 0.20 & 0.07 \\
\hline Sri Ayu Ningsih & 0.04 & 0.17 & 0.11 & 0.05 & 0.23 & 0.03 & 0.04 & 0.25 & 0.02 & 0.04 & 0.12 & 0.04 & 0.06 & 0.07 & 0.07 \\
\hline $\begin{array}{l}\text { Solusi Ideal } \\
\text { Positif A }\end{array}$ & 0.04 & 0.17 & 0.11 & 0.08 & 0.28 & 0.04 & 0.11 & 0.25 & 0.08 & 0.06 & 0.12 & 0.13 & 0.06 & 0.20 & 0.20 \\
\hline $\begin{array}{l}\text { Solusi Ideal } \\
\text { Negatif A }\end{array}$ & 0.02 & 0.17 & 0.11 & 0.03 & 0.06 & 0.02 & 0.04 & 0.05 & 0.02 & 0.01 & 0.06 & 0.04 & 0.02 & 0.07 & 0.07 \\
\hline
\end{tabular}

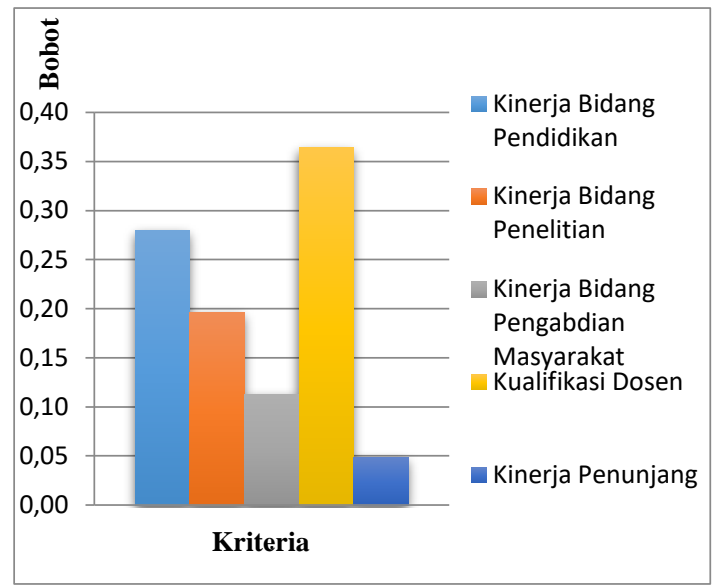

Tabel 9. Nilai Preferensi untuk Setiap Alternatif

\begin{tabular}{|l|c|c|c|c|}
\hline \multicolumn{1}{|c|}{ Alternatif } & D+ & D- & Preferensi & Rangking \\
\hline Iwan Darmawan & 0.10 & 0.34 & 0.771 & 1 \\
\hline Rina Asparina & 0.13 & 0.34 & 0.730 & 2 \\
\hline Masrudi & 0.15 & 0.30 & 0.660 & 3 \\
\hline Agus Fatarudi & 0.18 & 0.31 & 0.638 & 4 \\
\hline Dewi Utami Putri & 0.21 & 0.24 & 0.529 & 7 \\
\hline Denny Sarmadi & 0.33 & 0.18 & 0.360 & 9 \\
\hline Asnandar & 0.42 & 0.31 & 0.426 & 8 \\
\hline Ardilia Az Zahra & 0.55 & 0.20 & 0.269 & 10 \\
\hline Iyan Sampuraga & 0.19 & 0.26 & 0.575 & 5 \\
\hline Sri Ayu Ningsih & 0.24 & 0.27 & 0.534 & 6 \\
\hline
\end{tabular}

Gambar 2. Grafik Bobot Kepentingan Antar Kriteria

\subsection{TOPSIS}

Setelah proses Pair-wise comparation untuk kriteria dan sub kriteria dengan metode AHP, tahap selanjutnya adalah mengevaluasi alternatif dengan menggunakan TOPSIS. Terdapat 10 calon dosen berprestasi sebagai sampel dimana setiap calondosen berprestasi diberikan skor sesuai dengan situasi dan kondisi pada saat dilakukan penilaian. Skala yang digunakan untuk menilai calon dosen berprestasi berbeda-beda. Kehadiran (C11) memiliki skala nilai 1 untuk kehadiran dibawah $80 \%$, nilai 3 untuk kehadiran antara 81\%-90\% dan nilai 5 untuk kehadiran antara 91\%-100\%. GBPP dan SAP (C12), Bahan Ajar (C13), Kemahasiswaan (C51) dan Asosiasi Profesi (52) memiliki sifat penilaian ada (3) dan tidak ada (1). Sedangkan untuk Banyaknya Penelitian (C21), Jurnal (C22), Pembicara dalam Seminar (C23), Pengabdian (C31), Pelatihan (C32), Konsultasi/Pemberian Alat (C33), Pendidikan Bergelar (C41), Jabatan Fungsional (C42), Pendidikan Non Gelar (43), dan Jabatan Tambahan (53) memiliki skala nilai 1-5. Nilai 1 untuk menandakan sangat kurang dan nilai 5 untuk menandakan sangat baik. Hasil penilaian calon dosen berprestasi dapat dilihat pada tabel 6 .

Nilai-nilai pada skor setiap sub kriteria akan digunakan untuk membangun matriks keputusan ternormalisasi (normalized decision matrix). Elemen $\mathrm{r}_{\mathrm{ij}}$ hasil dari normalisasi didapatkan dari kuadrat tiap nilai dan dijumlahkan perkolom kemudian total penjumlahan tersebut diakarkan, kemudian hasil akar tersebut digunakan untuk membagi nilai-nilai pada kolom tersebut sehingga hasilnya dapat dilihat pada tabel 7.

Matriks keputusan ternormalisasi terbobot (weighted normalized decision matrix) diperoleh dengan mengalikan setiap baris pada matriks keputusan ternormalisasi (tabel 7) dengan bobot masing-masing kriteria yang telah diperoleh melalui perhitungan AHP sebelumnya (tabel $5)$.

Matriks keputusan ternormalisasi terbobot akan menentukan solusi ideal positif $\left(\mathrm{A}^{+}\right)$dan solusi ideal negatif $\left(\mathrm{A}^{-}\right)$. Solusi ideal positif $\left(\mathrm{A}^{+}\right)$diperoleh dari nilai terbesar dari tiap kolom kriteria. Sedangkan solusi ideal negatif $\left(\mathrm{A}^{-}\right)$di peroleh dari nilai terkecil dari tiap kolom kriteria.

Untuk menghitung separation measure ideal positif $\left(\mathrm{S}^{+}\right)$yaitu dengan mengurangi nilai matriks keputusan ternormalisasi terbobot dengan nilai solusi ideal positif $\left(\mathrm{A}^{+}\right)$lalu di kuadratkan 
kemudian dijumlahkan tiap barisnya, hasil dari penjumlahan itu kemudian diakarkuadratkan untuk menghasilkan separation measure ideal positif $\left(\mathrm{S}^{+}\right)$. Sedangkan untuk menghasilkan separation measure ideal negatif $\left(\mathrm{S}^{-}\right)$dilakukan dengan cara yang sama dengan nilai solusi ideal negatif $\left(\mathrm{A}^{-}\right)$.

Hasil perhitungan separation measure ideal positif dan separation measure ideal negatif digunakan untuk menentukan nilai preferensi setiap alternatif $\left(\mathrm{C}_{\mathrm{i}}\right)$. Nilai preferensi di peroleh dengan cara membagi nilai separation measure ideal negatif $\left(\mathrm{S}^{-}\right)$dengan jumlah dari separation measure ideal positif $\left(\mathrm{S}^{+}\right)$dan separation measure ideal negatif $\left(\mathrm{S}^{-}\right)$. Nilai preferensi setiap alternatif digunakan untuk menentukan dosen berprestasi seperti terlihat pada Tabel 9.

\subsection{Pembahasan}

Hasil penghitungan dengan metode AHP dan TOPSIS dapat dilihat bahwa Iwan Darmawan menduduki rangking 1 dengan preferensi tertinggi yaitu 0.771dengan jarak solusi ideal positif $\left(\mathrm{D}^{+}\right)$terendah yaitu 0.10 dan jarak solusi ideal negatifnya $\left(\mathrm{D}^{-}\right)$terbesar yaitu 0.34 . Berbeda dengan Ardilia Az Zahra yang menduduki rangking 10, nilai preferensi tertinggi yaitu 0.269 dengan jarak solusi ideal positif $\left(\mathrm{D}^{+}\right)$tertinggi yaitu 0.55 dan jarak solusi ideal negatifnya (D) terendah yaitu 0.20 . Hal tersebut menunjukan bahwa semakin kecil jarak solusi ideal positif makanilai tersebut mendekati kebenaran. Dilihat daribidang pengajaran, Iwan Darmawan mendapat nilai cukup untuk kehadiran, mempunyai GBPP dan SAP sertabahan ajar. Di bidang penelitian, dari jumlah penelitian yang dihasilkan termasuk kategori cukup, jumlah jurnal yang diterbitkan dan sebagai pembicara dalam seminar Iwan Darmawan termasuk kategori baik. Bidang Pengabdian kepada masyarakat yang dilakukan Iwan Darmawan tergolong cukup untuk organisasi kemasyarakatan dan hibah alat atau sebagai konsultan, sementara pemberian pelatihan kepada masyarakat termasuk kategori baik. Bidang Kualifikasi dosen pada kategori pendidikan bergelar dan Jabatan Fungsional Iwan Darmawan termasuk baik, serta pendidikan non gelarnya termasuk cukup. Dalam bidang kinerja penunjang pada kategori keterlibatan dalam kegiatan kemahasiswaan dan asosiasi profesi Iwan Darmawan termasuk baik, tetapi termasuk kurang di kategori jabatan tambahan.

Berbeda dengan Ardillia Az Zahra yang mendapatkan nilai preferensi terendah pada pemilihan dosen berprestasi. Pada bidang pengajaran, Ardilia Az Zahra termasuk baik dalam kategori kehadiran, mempunyai GBPP dan SAP, serta bahan ajar. Bidang penelitian, dalam kategori banyaknya penelitian, jumlah jurnal yang dipublikasikan, dan sebagai pembicara dalam seminar, Ardilia Az Zahra termasuk baik. Dalam bidang pengabdian kepada masyarakat, Ardilia Az Zahra termasuk kurang dalam kategori organisasi kemasyarakatan, sedangkan pada kategori pelatihan yang diberikan kepada masyarakat dan sebagai konsultan atau hibah alat termasuk sangat kurang. Bidang Kualifikasi dosen pada kategori pendidikan bergelar dan jabatan fungsional, Ardilia Az Zahra termasuk kurang, sementara pendidikan non gelar termasuk cukup. Dalam bidang kinerja penunjang, Ardilia Az Zahra termasuk baik pada kategori keterlibatan dalam kegiatan kemahasiswaan, dan termasuk kurang pada kategori asosiasi profesi, serta termasuk sangat kurang pada kategori jabatan tambahan.

Dari kedua nilai preferensi, baik yang memiliki nilai preferensi yang tertinggi maupun yang memiliki nilai preferensi terendah dalam pemilihan dosen berprestasi dapat dilihat bahwa tidaklah cukup hanya mempertimbangkan satu sisi saja dari kriteria penilaian. Dalam pembuatan keputusan yang objektif diperlukan beberapa kriteria dan sub kriteria sesuai preferensi pembuat keputusan. Pengambilan keputusan secara subjektif tidak akan menghasilkan keputusan yang baik dan cenderung kontradiktif.

Misalnya Iwan Darmawan kehadiran dan penelitian mendapat nilai cukup, kalah dibandingkan dengan Ardilia Az Zahra yang kehadiran dan penelitianya bernilai baik. Tetapi Iwan Darmawan mempunyai nilai yang sangat baik pada pemberian pelatihan pada masyarakat, mempunyai nilai yang baik pada jabatan fungsional dan asosiasi profesi. Sementara Ardilia Az Zahra mempunyai nilai cukup untuk pendidikan non gelar, nilai kurang pada organisasi kemasyarakatan, pendidikan bergelar, jabatan fungsional, pelatihan pada masyarakat, 
konsultan/hibah alat pada masyarakat, dan asosiasi profesi. Sedangkan untuk nilai sangat kurang pada jabatan tambahan. Tetapi Ardilia Az Zahra memiliki nilai baik di alternatif kriteria lainnya.

Dengan adanya pendukung keputusan, tim penilai dosen berprestasi akan lebih baik dalam mengambil keputusan, karena apabila tim penilai hanya menggunakan kriteria pengajaran saja maka tidak terpenuhinya Tridarma Perguruan Tinggi dan banyak dosen yang memiliki nilai yang sama. Nilai yang sama ini menimbulkan kecenderungan penilaian subjektif untuk menentukan dosen yang berprestasi.

\section{KESIMPULAN}

Penerapan Multiple Criteria Decision Making untuk Pemilihan Dosen Prestasi yang menggunakan metode AHP dan TOPSIS dapat digunakan sebagai pendukung keputusan yang multi kriteria dan memerlukan banyak pertimbangan. Metode AHP dan TOPSIS dapat membedakan dengan jelas berdasarkan nilai preferensi yang dihasilkan sehingga memberikan keputusan yang objektif. Khusus untuk tim penilai Dosen berprestasi, penerapan Multiple Criteria Decision Makingakan membantu mereka dalam pemilihan dosen berprestasi.

\section{SARAN}

Untuk penelitian selanjutnya dapat menambahkan lebih banyak alternatif dan tidak terbatas hanya dengan jumlah alternatif tertentu dan dapat mengembangkan kriteria menjadi sejumlah sub kriteria agar hasil dalam menentukan tingkat prioritas akan menjadi lebih maksimal sehingga pembuat keputusan bisa mendapatkan bobot yang baik. Selain itu bisa dibangun sistem pendukung keputusan sehingga dapat membantu pengambil keputusan.

\section{DAFTAR PUSTAKA}

[1] Risbang Ristekdikti, 2012, Undang-Undang Republik Indonesia Nomor 12 Tahun 2012, risbang.ristekdikti.go.id/regulasi/uu-12-2012.pdf, diakses tgl 5 September 2017

[2] Kelembagaan.ristekdikti Nomor : 54/SP/HM/BKKP/IV/2017, 2017, 100 Besar Perguruan Tinggi Non Politeknik dan 25 Besar Perguruan Tinggi Politeknik di Indonesia Tahun 2017, http://www.dikti.go.id/100-besar-perguruan-tinggi-non-politeknik-dan-25-besar perguruan tinggi-politeknik-di-indonesia-tahun-2017/, diakses tgl 5 September 2017.

[3] Kemenristekdiktik, 2017, Pedoman Pemilihan Dosen Berprestasi Kategori Sains Teknologi dan Sosial Humaniora tahun Anggaran 2017, sumberdaya.ristekdikti.go.id/wpcontent/uploads/2016/02/Dosen-Brepestasi.pdf, diakses tgl 3 September 2017.

[4] Tavana, M., \& Hatami-Marbini, A. (2011). A group AHP-TOPSIS framework for human spaceflight mission planning at NASA. Expert Systems with Applications, 38(11), 1358813603.

[5] Chen, J. K., Chang, C. S., \& Le Huyen, N. T. (2013, December). Multiple criteria model for evaluation and selection of outsourcing service countries: A case study in the East and Southeast Asia. In Industrial Engineering and Engineering Management (IEEM), 2013 IEEE International Conference on (pp. 887-891). IEEE.DOI: 10.1109/IEEM.2013.6962539

[6] Karim, R., Karmaker, C. L., 2016, Machine Selection by AHP and TOPSIS Methods. American Journal of Industrial Engineering, Vol 4 No 1 Hal 7-13.

[7] Kahriman, A., Öztokatl1, M., \& Daş, G. S. (2015, June). Selection of a communication satellite manufacturer using MCDM methods.In Recent Advances in Space Technologies (RAST), 2015 7th International Conference on (pp. 347-351).IEEE. DOI: 10.1109/RAST.2015.7208368

[8] Kusumadewi, S., Hartati, S., Harjoko, A., \& Wardoyo, R. Fuzzy Multi-Atribute DecisionMaking (1st Edition ed.). Yogyakarta: Graha Ilmu, 2006 
[9] Venkatesh, V. G., Dubey, R., Joy, P., Thomas, M., Vijeesh, V., \& Moosa, A. (2015). Supplier selection in blood bags manufacturing industry using TOPSIS model. International Journal of Operational Research, 24(4), 461-488.

[10] Hasan, H. (2015). Sistem Pendukung Keputusan Pemilihan Paket Umroh (Studi Kasus: PT. Amanah Iman). Proceedings Konferensi Nasional Sistem dan Informatika (KNS\&I).

[11] Saaty, Thomas L., 2000, Fundamentals of Decision Making and Priority Theory with The Analytic Hierarchy Process (Analytic Hierarchy Process Series, Vol. 6), First Edition, RWS Publications. 